\title{
Advertising Effectiveness and Influence of Consumer Buying Decision of LED Television
}

\author{
Md. Jamal Uddin ${ }^{1}$, Md. Mostafizur Rahman²*, Abul Kalam³, Md. Ferdush Rahman ${ }^{4}$ \\ ${ }^{1,3}$ Associate Professor, Department of Marketing, Hajee Mohammad Danesh Science and Technology University, Dinajpur, BANGLADESH \\ ${ }^{2}$ Assistant Professor, Department of Management, Hajee Mohammad Danesh Science and Technology University, Dinajpur, BANGLADESH \\ ${ }^{4}$ Associate Professor, Department of Marketing, Begum Rokeya University, Rangpur, BANGLADESH \\ "E-mail for correspondence: mostafiz@hstu.ac.bd
}

https://doi.org/10.18034/abr.v9i3.272

\begin{abstract}
The main aim of the present study was to identify the influence of advertising effectiveness on the consumer buying decisions of different brands of 'LED' television. The study was descriptive. Five television showrooms in Dinajpur district, Bangladesh (Sony, Singer, Samsung, LG, and Walton) were purposively selected for collecting primary data for this study. The respondents were selected using a convenience sampling method that came to the television showroom for purchasing 'LED' television. The primary data for this study were collected through a structured questionnaire. The study result shows that advertisement has a positive effect on consumer buying decisions of 'LED' television, Sony brand $(p=.000<0.05)$ and $43.9 \%$ of variation in consumer buying decision has been contributed by advertisement effectiveness. For Singer brand $p=.010<0.05$ ), Samsung brand $p=.003<0.05$ ), LG brand $\mathrm{p}=.341>0.05$ ) and the null hypothesis is accepted for LG band and Walton brand $\mathrm{p}=.000<0.05$ ) and $42.3 \%$ of variation in consumer buying decision has been contributed by advertisement effectiveness.
\end{abstract}

Key words: Advertising, LED television, Consumer, Buying decision

\section{INTRODUCTION}

In the vibrant and multifarious world business atmosphere is becoming refined day by day and as such, decisionmaking is challenging and risky. Business organizations are failing due to poor decisions. Investors are losing their money and are unhappy. Some are successful in the marketing of their products and services, while others are still akin to the barber's chair syndrome where all is motion but no movement, struggling to reach their target audience. Consumers are also faced with the challenge of choicemaking due to indecisiveness, skepticism, indifference, and confusion, which are among the key sales killers in the business world (Ezeoha, 2007). So many companies spend so much money on advertising, sales promotion, point of purchase displays and other marketing communications only to discover that many people don't even remember the product or the promotion. On the other hand, whether consumers ultimately purchase the marketer's brand also depends on whether the promotion and marketing communication variables facilitate purchasing. Among the whole marketing tools, the advertising is distinguished for the continuing impact on the observer's mind as its impact is broader. Basically, advertisement is a tool of the promotional mix that includes the 4p's of the marketing mix as well as Product, Price, Place and Promotion. Presently advertisement is a great source for promotion. The consequences of advertisement continue to speed up by every year. Advertisement use to build up the product's robust image in consumer's attention. Advertisement helps the company to create awareness in its customers and ingredients the advertisements shape the perception of the customers positively. People can perceive the quality of the products by gathering the information which they usually get through advertisements. The perception of the quality, awareness of the product and consumer opinion drives the consumer buying decision (Fatima and Lodhi, 2015). The present study evaluates the effectiveness of advertisement and its influence on consumer buying decision of 'LED' television.

\section{Objectives of the Study}

- To know the relationship between the consumer demographic and advertising effectiveness with consumer buying decisions of different brands. 
- $\quad$ To study the consumer opinion regarding the most effective media for advertisement.

- To identify the influence of the advertisement effectiveness on consumer buying decision of different brand of 'LED' television.

\section{Hypotheses}

$\mathbf{H}_{1}$ : There is no relation between the consumer demographic characteristics and buying decisions of different brands of television.

$\mathbf{H}_{2}$ : There is no relation between advertising effectiveness and buying decisions of different brands.

$\mathbf{H}_{3}$ : Advertising effectiveness does not influence the consumer buying decisions of different brand of television.

\section{LITERATURE REVIEWS}

Purushothaman et al. (2015) found that advertisement creates considerable impact and it paves the way for the customers to perceive the quality and other features of the product. Advertisements are very useful in creating the awareness among the people but they are failed to build strong perceptions in the mind of consumers. Both of these variables such as consumer awareness and consumer perceptions will motivate the consumer to buy a certain product, as there is a positive relationship present in between them (Fatima and Lodhi, 2015). Rafique (2012) argued that advertisement is a way to connect with the expected audience. People are highly affected by the advertisements and organizations are trying to target the masses of the people. Advertisement and consumer perception both have a significant positive relationship with consumer buying behavior. Consumer buying behavior can be enhanced with rich quality and creative advertisements and by building positive consumer perception through strong marketing strategies (Malik et al. 2014). Again, Rehman (2014) found that advertising has positive and statistically significant effects, while, the factors of rural areas have negative but statistically significant effects on consumers buying behavior. Further, advertising is positively but factors of rural areas are negatively correlated with consumers buying behavior. Advertisements shape the behaviors of the people through cognition, which is the perception of a person towards the information communicated through advertisements (Jakstiene, 2008). Sumathi \& Begum (2016) argued that advertising satisfies the needs of both the firm and the consumers. Its role cannot be replaced by any other means. Hence, firms must strategize and know when and where they should advertise. On the other hand Sharma and Sharma (2009) found in their study besides advertising other factors like company's brand, quality of the invention and company's reputation affect the sales of a company. Again, Barroso (2008) found when the sale of any product increases, it is because the consumer is aware about the product's value and this point is achieved through efficient advertisement about product. Sawant (2012) found that if the consumers experience dissonance or discomfort owing to their purchase decision, then advertisement reduces this feeling of discomfort by providing information on the products attributes. It is even more necessary to neutralize the impact of the advertisements of rival brands. Advertising is to impact on buying behavior and this impact about brand is changed or strengthened frequently people's memories. Memories about the brand consist of those associations that are related to brand name in consumer mind. These brand cognitions influence consideration, evaluation, and finally purchases (Romaniuk and Sharp, 2004). The above literature reviews regarding advertisement and buying behavior emerged with the gap, that no serious study was attempted at national and international level to determine the influence of advertising effectiveness on consumer buying decision of 'LED' television. So, the present could able to fill the gap of previous studies.

\section{Methodology OF THE Study}

This study was descriptive in nature. Five television showrooms in Dinajpur district, Bangladesh (Sony, Singer, Samsung, LG and Walton) were purposively selected for this study. 112 respondents (Sony- 27, Singer- 15, Samsung21, LG- 13 and Walton-36) were selected using convenience sampling method for collecting primary data. Data were collected from the respondents who came to the television showroom for the purpose of purchasing 'LED' television. The primary data for this study were collected through a well-structured questionnaire developed from literature review. A five-point Likert scale (where, $1=$ strongly disagree and $5=$ strongly agree) was used to evaluate the respondent opinion of different brands. Besides primary data, secondary data were also used in this study. The secondary data were collected from books, published journals, articles, and research papers. Collected primary data from the respondents were analyzed using the Statistical Package for Social Science (SPSS) software so as to obtain a more comprehensive analysis of the study. Simple percentage method was used to analysis the demographic characteristics of the respondents. Chi-square technique was used to find out the association between advertising effectiveness and consumer buying decision of different brands. Kendall's coefficient of concordance was used for ranking most effective media for advertisement and simple regression analysis was used to identify the influence of the advertisement effectiveness on consumer buying decision of different brand.

\section{RESULtS AND Discussion}

Table 1 shows the demographic characteristics of 'LED' television users. It is found that $69.64 \%$ respondents are male and $30.36 \%$ are female. Highest $42.86 \%$ respondent 
whose age belongs $31-35$ years and $29.47 \%$ respondents age in $36-40$ years. A limited number of respondent $1.79 \%$ is below SSC pass and maximum $60.71 \%$ respondent has post-graduate degree. Highest $52.68 \%$ respondents are service holder and $41.96 \%$ respondents are businessman. $16.96 \%$ respondents income limit between 30,001-40,000 tk., $29.46 \%$ respondents income limit between 40,001-50,000 tk. and $41.07 \%$ respondents income $>50,000$ tk. $24.11 \%$ respondents are Sony television users, $13.39 \%$ respondents are Singer television users, $18.75 \%$ respondents are Samsung users, $11.61 \%$ respondents are LG users and $32.14 \%$ respondents are Walton television users.

Table 1: Demographic characteristic of the respondents

\begin{tabular}{|l|c|c|}
\hline Demographics & $\begin{array}{c}\text { Number of } \\
\text { Respondents }\end{array}$ & Percentage \\
\hline Gender wise & 78 & \\
\hline Male & 32 & 69.64 \\
\hline Female & 112 & 30.36 \\
\hline Total & & 100.00 \\
\hline Age wise & 12 & 10.71 \\
\hline $25-30$ & 48 & 42.86 \\
\hline $31-35$ & 33 & 29.47 \\
\hline $36-40$ & 19 & 16.96 \\
\hline $40+$ & 112 & 100.00 \\
\hline Total & & \\
\hline $\begin{array}{l}\text { Educational } \\
\text { qualifications wise }\end{array}$ & 2 & 1.79 \\
\hline Below SSC & 5 & 4.46 \\
\hline SSC & 8 & 7.15 \\
\hline HSC & 29 & 25.89 \\
\hline Graduate & 68 & 60.71 \\
\hline Postgraduate & 112 & 100.00 \\
\hline Total & & \\
\hline Profession wise & 4 & 3.57 \\
\hline Unemployed & 59 & 52.68 \\
\hline Service & & \\
\hline
\end{tabular}

\begin{tabular}{|l|c|c|}
\hline Business & 47 & 41.96 \\
\hline Others & 2 & 1.79 \\
\hline Total & 112 & 100.00 \\
\hline Monthly income wise (Tk.) & & \\
\hline$<20,000$ & 4 & 3.57 \\
\hline $20001-30,000$ & 10 & 8.93 \\
\hline $30,001-40,000$ & 19 & 16.96 \\
\hline $40,001-50,000$ & 33 & 29.46 \\
\hline $50,000>$ & 46 & 41.07 \\
\hline Total & 112 & 100.00 \\
\hline Brand owned & & \\
\hline Sony & 27 & 24.11 \\
\hline Singer & 15 & 13.39 \\
\hline Samsung & 21 & 18.75 \\
\hline LG & 13 & 11.61 \\
\hline Walton & 36 & 32.14 \\
\hline Total & 112 & 100.00 \\
\hline Source: Fld
\end{tabular}

Source: Field survey data, January- March 2017

The following table 2 shows the association between consumer demographic characteristics and advertising effectiveness with buying decision of different brands. The positive association found monthly income of respondent and buying decision of 'LED' television, calculated chi-square value $\chi^{l}{ }_{c}=14.171, p=.003<0.05$, respondent profession and buying decision $\chi_{c}{ }_{c}=20.153$, $\mathrm{p}=.010<0.05$, respondent opinion on advertising is the best tool for promotion and buying decision $\chi_{c}^{{ }^{\prime}}=41.554$, $\mathrm{p}=.000<0.05$, advertising is very interesting, funny, exciting and buying decision $\chi_{c}^{2}=18.272, p=.011<0.05$, advertising is to remember and buying decision $\chi^{{ }^{2}}{ }_{c}=$ 28.623, $\mathrm{p}=.026<0.05$, advertising maintain buyer-seller relation and buying decision $\chi_{c}^{l}=18.272, p=.011<0.05$

Table 2: Chi-square test result

\begin{tabular}{|l|c|c|c|c|c|}
\hline & $\begin{array}{c}\text { Calculated } \\
\text { value }\left(\chi_{c}^{\prime}\right)\end{array}$ & $\begin{array}{c}\text { Likelihood } \\
\text { Ratio }\end{array}$ & $\begin{array}{c}\text { ' } \mathrm{p}^{\prime} \\
\text { value }\end{array}$ & Result \\
\hline $\begin{array}{l}\text { Association between sex of the respondent and buying decision of } \\
\text { different brands }\end{array}$ & 4.431 & 4.409 & 4 & .342 & Accepted \\
\hline $\begin{array}{l}\text { Association between age of the respondent and buying decision of } \\
\text { different brands }\end{array}$ & 16.673 & 17.550 & 12 & .160 & Accepted \\
\hline $\begin{array}{l}\text { Association between educational qualifications of the respondent and } \\
\text { buying decision of different brands }\end{array}$ & 27.137 & 26.426 & 16 & .211 & Accepted \\
\hline $\begin{array}{l}\text { Association between income of the respondent and buying decision of } \\
\text { different brands }\end{array}$ & 14.171 & 14.259 & 16 & .003 & Rejected \\
\hline $\begin{array}{l}\text { Association between profession of the respondent and buying decision } \\
\text { of different brands }\end{array}$ & 20.153 & 19.902 & 12 & .010 & Rejected \\
\hline
\end{tabular}




\begin{tabular}{|l|c|c|c|c|c|}
\hline $\begin{array}{l}\text { Association between respondent opinion on advertising is the best tool } \\
\text { for promotion and buying decision of different brand }\end{array}$ & 41.554 & 41.865 & 16 & .000 & Rejected \\
\hline $\begin{array}{l}\text { Association between respondent opinion on advertising provide } \\
\text { information about brand and buying decision of different brand }\end{array}$ & 9.378 & 8.520 & 16 & .813 & Accepted \\
\hline $\begin{array}{l}\text { Association between respondent opinion on advertising is very } \\
\text { interesting, funny, exciting and buying decision of different brand }\end{array}$ & 18.272 & 18.133 & 16 & .011 & Rejected \\
\hline $\begin{array}{l}\text { Association between respondent opinion on advertising is to remember } \\
\text { and buying decision of different brand. }\end{array}$ & 28.623 & 28.894 & 16 & .026 & Rejected \\
\hline $\begin{array}{l}\text { Association between respondent opinions on celebrity advertising is } \\
\text { important and buying decision of different brand. }\end{array}$ & 9.427 & 9.755 & 16 & .139 & Accepted \\
\hline $\begin{array}{l}\text { Association between respondent opinion on advertising maintain buyer- } \\
\text { seller relation and buying decision of different brand }\end{array}$ & 21.435 & 20.629 & 16 & .000 & Rejected \\
\hline
\end{tabular}

Table 3: Respondents opinion on most effective media for advertisement

\begin{tabular}{|l|c|}
\hline & Mean Rank \\
\hline Television & 2.36 \\
\hline Newspaper & 2.49 \\
\hline Point of purchase display & 2.98 \\
\hline Magazine & 3.60 \\
\hline Neon sign & 5.46 \\
\hline Billboard & 4.21 \\
\hline Poster & 3.11 \\
\hline Internet & 6.65 \\
\hline SMS advertising & 5.56 \\
\hline Kendall's W & .169 \\
\hline
\end{tabular}

Table 3 shows the respondent opinion on most effective advertisement media for buying decision of 'LED' television. By applying the Kendall's co-efficient of concordance, the mean rank shows that television is the top best media for advertising as indicated by respondent (mean rank 2.36), followed by newspaper advertising (mean rank 2.49), followed by point of purchase display (mean rank 2.98), then poster (mean rank 3.11), then magazine (mean rank 3.60), then billboard (mean rank 4.21), then neon sign (mean rank 5.46), then SMS advertising (mean rank 5.56), then internet (mean rank 6.65). By ranking the priority items from 1-9, the top association item got the rank of 1 and the least priority item got the rank of 9. The Kendall's W is found 0.169.

Table 4: Simple regression analysis result of different brand

\begin{tabular}{|c|c|c|c|c|c|c|}
\hline Brand & $\beta$ & $\begin{array}{c}\text { Std. } \\
\text { Error }\end{array}$ & $\mathrm{t}$ & Sig. & $\mathrm{R}$ & $\begin{array}{c}\mathrm{R} \\
\text { Square }\end{array}$ \\
\hline Sony & .041 & .532 & 2.321 & .000 & .411 & .439 \\
\hline Singer & 1.941 & .429 & 1.693 & .010 & .524 & .293 \\
\hline Samsung & 1.231 & .282 & 1.906 & .003 & .349 & .321 \\
\hline LG & .518 & .432 & .782 & .341 & .241 & .232 \\
\hline Walton & .935 & .121 & 2.221 & .000 & .540 & .423 \\
\hline
\end{tabular}

Independent variable: Advertisement effectiveness Dependent variable: Buying decision
Simple linear regression analysis is applies to find the influence of advertising effectiveness on customer buying decision of different brand of 'LED' television. For Sony brand the regression result shows that advertisement has a positive effect on consumer buying decision ( $\mathrm{p}=.000<0.05)$. So, null hypothesis is rejected. The $\mathrm{R}$ square value is (.439) which indicates that $43.9 \%$ of variation in consumer buying decision has been contributed by advertisement effectiveness. For Singer brand $p=.010<0.05$ and $29.3 \%$ of variation in consumer buying decision has been contributed by advertisement effectiveness. For Samsung brand $\mathrm{p}=.003<0.05$ and $32.1 \%$ of variation in consumer buying decision has been contributed by advertisement effectiveness. For LG brand $p=.341>0.05$ and the null hypothesis is accepted for LG band. For Walton brand $\mathrm{p}=.000<0.05$ and $42.3 \%$ of variation in consumer buying decision has been contributed by advertisement effectiveness. So, the null hypothesis is rejected for Walton brand.

\section{Conclusion}

This study is related to advertising effectiveness and its influence of consumer buying decision of 'LED' television. According to the study profile it is found that maximum numbers of respondents $32.14 \%$ are Walton television user and $24.11 \%$ respondents are Sony television user. $29.46 \%$ respondents income limit between 40,001-50,000 tk. and $41.07 \%$ respondents income $>50,000 \mathrm{tk}$. Chi-square test result found a positive association between monthly income of respondent and buying decision of 'LED' television $\chi^{\prime}{ }_{c}=$ $14.171, \mathrm{p}=.003<0.05)$. Positive association also found between respondent profession and buying decision $\left(\chi_{c}{ }_{c}=20.153\right.$, $\mathrm{p}=.010<0.05$ ). Television is the top best media for advertising as indicated by respondent (mean rank 2.36) and newspaper advertising (mean rank 2.49). Regression result shows that except LG brand advertisement has a positive effect on consumer buying decision of all brand of 'LED' television. 
The R square value of regression result shows that for Sony brand $43.9 \%$, Singer brand $29.3 \%$, Samsung brand $32.1 \%$, Walton brand $42.3 \%$ of variation in consumer buying decision has been contributed by advertisement effectiveness. It has been conclude that before purchasing any product customers collects information for their proper purchasing decision making activities, hence advertisement is mostly adopted to get information about the products. In our study we found advertising effectiveness has great impact on consumer buying decision of different brand of 'LED' television. Therefore, advertisers must use such advertisement to establish their brand identity and creating awareness in consumer about the product.

\section{REFERENCES}

Barroso, A. (2008). Advertising and Consumer Awareness of a New Product. Centre for Economic Policy Research Paper, 3:1-30.

Ezeoha, U.V. (2007). An Evaluation of the Impact of Advertising on Consumer Behavior (A Case Study of De-United Industries Ltd.: Makers of Indomie Noodles) MBA Thesis, University of Nigeria.

Fatima, S. \& Lodhi, S. (2015). Impact of advertisement on buying behavior of the consumers: stauy of cosmetic industry in Karachi city, International Journal of Management Sciences and Business Research, 4(10): 125-137.

Jakstiene, D. S. (2008). The Psychological Impact of Advertising on the Customer Behavior. Communications of the IBIMA, 3: $50-55$.
Malik, M., E., Ghafoor, M., M., and Iqbal, H., K., (2014). “Impact of Brand Image, Service Quality and price on customer satisfaction". International Journal of Business and Social Science. 3: 123-129.

Purushothaman G., Purushothaman, V. M. and Krishnamurthy, K. (2015). A Study on Impact of Advertisement on Buying Behavior of Consumers in Tamil Nadu (With Special Reference Two Wheeler Customers in Kanchi Puram) Journal of Sales and Marketing Management (JSMM). 5(1): 13-18.

Rafique, Y. (2012). Impact of advertisement on consumer behavior of FMCG in Lahore City. Academic Research International, (2)3: 571-574.

Rehman, F. (2014). How Advertising Affects the Buying Behavior of Consumers in Rural Areas: A Case of Pakistan, Academic Research International. 5(4): 405-412.

Romaniuk, J. and Sharp, B. (2004). Conceptualizing \& Measuring Brand Salience. Marketing Theory Articles. 4(4):327-342.

Sawant, R.P. (2012). Impact of Advertising on Brand Awareness and Consumer Preference (With Special Reference to Men`S Wear). Journal of Business and Management. 5(6): 54-61.

Sharma J and Sharma S. (2009). "Sales and Advertisement Relationship for Selected Companies Operating in India", School of Doctoral Studies (European Union) Journal July, 2009, No. 1

Sumathi and Begum, M. (2016). Impact of Advertisements on Consumer Behavior of Cosmetic Products- A study in Mangalore. International Journal of Scientific Research and Modern Education. 1(I):874-879. 
Online Archive: https://abc.us.org/ojs/index.php/abr/issue/archive 